\title{
Journal of
}

Strategic Management

(JSM)

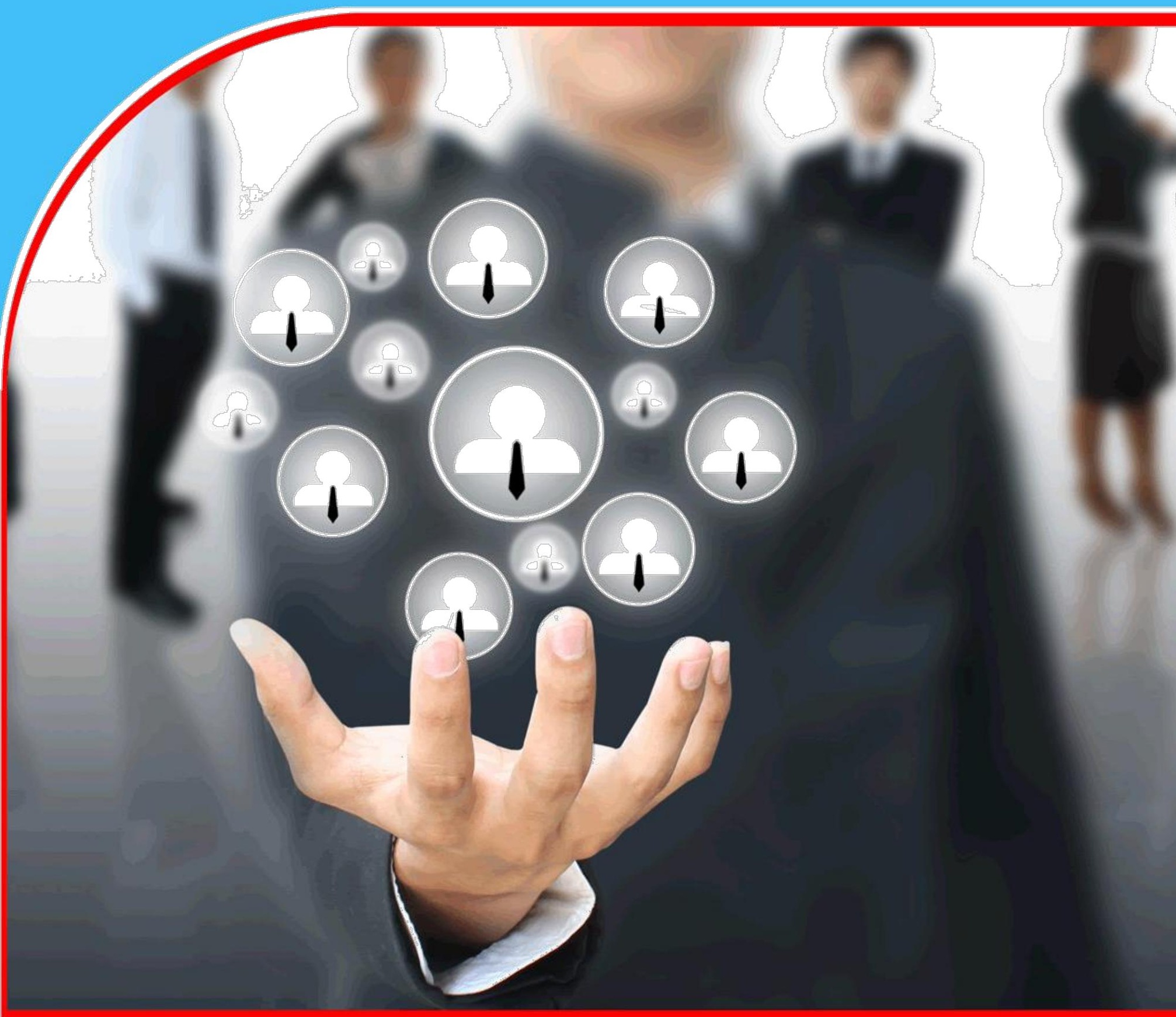

EFFECT OF MANAGEMENT EFFICIENCY ON FINANCIAL PERFORMANCE OF SAVINGS AND CREDIT SOCIETIES IN KENYA

Jane J. Barus, Prof. Willy Muturi, Dr. Patrick Kibati and Dr. Joel Koima 


\title{
EFFECT OF MANAGEMENT EFFICIENCY ON FINANCIAL PERFORMANCE OF SAVINGS AND CREDIT SOCIETIES IN KENYA
}

\author{
1*Jane J. Barus \\ Post Graduate Student: School of Business \\ ${ }^{2}$ Prof. Willy Muturi, \\ Lecturer, School of Business \\ ${ }^{3}$ Dr. Patrick Kibati \\ Lecturer, School of Business \\ ${ }^{3}$ Dr. Joel Koima \\ Lecturer, School of Business
}

Jomo Kenyatta University of Agriculture and Technology

*Corresponding Author's E-mail: jane.barus@yahoo.com

\begin{abstract}
Purpose: The purpose of this study was to evaluate the effect of management efficiency on financial performance of savings and credit societies in Kenya.

Methodology: The study employed an explanatory research design. The target population was 83 registered deposit taking SACCO's in Kenya that have been in operation for the last five years. The sample size for the study was all 83 SACCOs that have remained in existence since 2011-2015. Census methodology was used in the study. Both primary and secondary sources of data were employed. Multiple linear regression models were used to analyze the data using statistical package for the social sciences (SPSS) and STATA. A pilot study was conducted to measure the research instruments reliability and validity. Descriptive and inferential analysis was conducted to analyze the data. The data was presented using tables and graphs.

Results: Based on the findings the study concluded that management efficiency has no significant influence on the financial performance of savings and credit societies in Kenya. The univariate regression results showed that management efficiency has no significant influence on the financial performance of savings and credit societies $(\mathrm{p}=0.173)$.

Unique contribution to theory, practice and policy: The study recommended that with regard to credit risk management, the management should undertake measures to improve Capital adequacy, Asset quality, Management efficiency, Earnings and Liquidity. Further, the study recommended that SACCO's should train their employees as this is likely to increase their productivity.
\end{abstract}

Keywords: management efficiency, financial performance, savings and credit societies 


\subsection{INTRODUCTION}

\subsection{Background of the Study}

The SACCO industry in Kenya plays a very important role as the financial intermediary between savers and investors. The first ever SACCO was established in 1844 by Robert Owen (John, 2002). SACCO's belong to a group of cooperatives that are commonly called Raiffeisen cooperatives due to the German originator of this movement in the 1800s (Tache, 2006). SACCO's are guided by seven principles as stipulated by the International Cooperative Alliance (ICA); Open and voluntary membership, member economic participation, independence and autonomy, democratic member control, education, training and information, Concern for Community and Cooperation among Cooperatives. SACCO's are expected to give better and cheaper services to its members as compared to the main stream banks because SACCO's understands the needs of the members given that they are the owners (Wanyama, Develtere \& Pollet, 2008). Services offered by SACCO's include normal loans, emergency loans, school fees loans and front office services for example; payment of salaries, salary advances, bank cheques, safe keeping of documents, and ATMs (Ngaira, 2011).

According to (ICA, 2009) Rochdale Pioneers was the founder of the contemporary Cooperative Movement in Lancashire, England, to deliver cheap alternative to poor-quality and adulterated food and provisions food, by the use of surplus so as to benefit the community. Subsequently, the co-operative movement has succeeded spreading throughout the world and incorporating all parts of the economy. The principles that supported cooperatives ways of doing trade is still recognized today as the basis upon which all co-operatives operate. However, the principles has been looked over and updated.

Globally, the sector has 1 billion memberships. It is estimated that co-operatives have employed 250 million people all over the world, co-operatives has an estimated global turnover of 2.2 trillion US Dollars, Co-operative generate 2.2 trillion US\$ in turnover while providing infrastructure and services that the society needs to flourish. Global statistical report for 2014, recorded a total of 57,000 Credit Unions (SACCO's), spread across 105 countries and 6 continents. The world Credit Union system has a combined savings of 1.5 trillion US\$, and an asset base of 1.8 trillion US\$ out of which 1.2 trillion US\$ constitutes the loan portfolio. The average worldwide penetration rate of the Credit Union system stood at 8.2 percent World Co-operative Monitor (2014).

Globally, efficiency of community banks was analyzed in the United States (US) using data from year-end 2006-2008. Multivariate discriminant model was used based on the CAMEL(S) model, to differentiate between low efficiency and high efficiency community banks by using the efficiency ratio as the independent variable. The results on the significance of the individual CAMEL components provide mixed results for different periods apart from the sensitivity to market risk, which is found to be statistically insignificant (Hays, Stephen\& Arthur, 2009).

In India, the soundness of Indian Banking through its effect on the asset value was analyzed. The study recognized the key players such as the risk management, Non Performing Assets (NPA) levels, effective cost management and financial inclusion. Moreover, In India performance of different Indian private and public sectors banks over the period 2000-2011 were analyzed using the CAMEL approach and established out that the private sector banks 
were at the top, with their performance being the best in terms of soundness (Chaudhry \&Singh, 2012).

In Africa growth of SACCO's has been experienced to the extent that in 1965, Africa Federation of Cooperative Societies Savings and Credit Association (ACCOSSCA) was formed with the principle objective of offering SACCO insurance, education to members and promoting SACCO principles(Ng'ombe \& Mikwamba, 2004). There are 28 countries in the continent of Africa with established SACCO's (saving plus, 2010). Africa has membership of 16 million which is 8 percent of the whole world membership, with savings of $62 \%$ and loans of $65 \%$ being $3{ }^{\text {rd }}$ after Asia and North America which has 36 million and 102 million respectively. Africa mobilize 0.4 percent of the worldwide savings of US\$ 1.1 trillion and 0.4 percent of international loans given to members standing at US\$ 912 billion (WOCCU, 2009).In Africa, performance of the South African Banking Sector was analyzed from 1994 and found out that all bank-specific variables were statistically significant at conventional level for both Return on Assets (ROA) and Return on Equity (ROE) equations. The study had shown that Asset Quality (measured by assets to capital employed ratio), Management Efficiency (measured by operating profits per employee ratio), and Liquidity Management (measured by quick ratio) has positive relationship with both measures of bank performance, which is consistent with a priori theoretical expectations. However, the Leverage Ratio, which is a measure of Capital Adequacy, shows a surprising significant negative relationship with ROA, whereas its relationship with ROE is significant and positive as expected, (Ifeacho \& Ngalawa, 2014).In Ghana CAMEL Rating System was used to assess the Performance of Local and Foreign Banks results from the study indicated that not all the CAMEL variables affect Banks performance in Ghana in terms of ROA and ROE (Ansah, 2015).

In East Africa the East African Legislative Assembly (EALA) passed the East African Community (EAC) Cooperative Societies Bill, 2014. The Bill is currently awaiting assent by the East African Community Heads of States in line with Article 63 of the EAC Treaty. The objective of the EAC Cooperative Societies Bill, 2014 is to provide a legal framework for the operations of Co-operative Societies within the Community, which is in line with Article 128 of the EAC Treaty on the strengthening of the role of private sector as an effective force for developing economies, by virtue of EAC Treaty and Article 2(6) of Kenyan Constitution 2010 which recognizes that treaties ratified by Kenya are part of the laws of Kenya, the Kenyan National Legislations on Co-operatives will be required to be aligned to EAC Cooperative Societies Bill, 2014 once it becomes law. The Bill is based on the understanding that each Partner State shall undertake to encourage the efficient use of resources and to promote the development of private sector organizations which are engaged in all types of economic activities, such as the chambers of commerce and industry, confederations and associations of industry, agriculture among others. It also recognized the responsibility of state parties to enact national legislations to govern the operations of co-operative societies within the party states. In Ethiopia Zerfeshewa (2010), investigated the determinants of SACCO performance; the study established that the educational level of members and officials as well as the regulations posed the greatest impediment to the performance of SACCO's. 


\subsection{Problem Statement}

The SACCO's subsector remains a significant player in the provision of financial services to the Kenya household and small business segment. Its membership as per 2013 increased to 3.3 million from 2.97 million in 2012. SACCO's plays a vital role of pooling resources for investment and wealth creation (Kinyua, 2013). They spur economic growth through the mobilization of domestic savings. According to SASRA report (2010), SACCO activities contribute $43 \%$ of the gross domestic product (GDP).

The significance of SACCO's to the Kenyan economy is further evidenced by inclusion in the Vision 2030 economic blue print (Kioko, 2014). Given their significance in the financial sector and poverty alleviation, it is important to investigate the moderating effect of sensitivity to market risk on determinants of performance in order to provide accurate and consistent assessment of savings and credit financial conditions and operations in the area of performance. Zerfeshewa (2010) investigated the determinants of SACCO performance in Ethiopia; Sonja (2010) analyzed SACCO's in Uganda to determine effect of automation on the growth of SACCO's.

Based on these studies and the varying gaps in literature, there is need to conduct similar studies in Africa and more so in Kenya. Therefore, the research attempted to evaluate the effect of management efficiency on the financial performance of savings and credit societies in Kenya.

\subsection{Research Objective}

To evaluate the effect of management efficiency on financial performance of savings and credit societies in Kenya

\subsection{LITERATURE REVIEW}

\subsection{Theoretical Framework}

\subsubsection{Efficient Structure Theory}

This theory was formulated by Modigliani and millers, 1950 through the approach to capital theory advocating capital structure irrelevancy theory; they further states that the market value of a firm is affected by its future growth prospect apart from the risk involved in the investment. Its prepositions were that there is no transaction cost and individual and corporate borrow at the same rate. According to Thoraneenitiyan, (2010), Bank efficiency studies can be separated into those that examine scale and scope efficiency and those that examine $\mathrm{X}$ efficiency or frontier efficiency. The X-efficiency hypothesis argues that banks with better management and practices raise profits and control costs, moving the bank closer to the bestpractice. The scale-efficiency hypothesis argues that some banks achieve better scale of operation and, thus, lower costs. Lower costs lead to growth and higher profits. Berger (1995) argues that previous research on tests of the market-power theories produce suspect findings, since they as a rule do not control for the efficient-structure theories. He found out that support for only two of the four hypotheses - the relative-market-power and the X-efficiency hypotheses using simultaneous test of all four competing hypotheses - two market-power and two efficient structure by adding measures of X-efficiency and scale efficiency to the standard tests. 
Empirically tested this hypothesis ("Efficient-Structure" theory) using data set over 2700 banks, he found no relationship between market concentration and bank profitability, while significant positive correlation between bank profitability and market share was present (Smirlock, 1985). The efficiency structure theory is relevant to this study as it guides the SACCO management efficiency.

\subsubsection{Expense-Preference Behavior theory}

Expense-Preference behavior theory is one of the most employed in the research. This theory was developed by Williamson (1963) and later refined by (Rees, 1974), this theory posits individual preferences of managers of a firm as utility maximizing, as opposed to profit maximizing. It predicts that under certain conducive circumstances such as the separation of ownership and control, costly monitoring of managerial behavior, a lack of effective competition in input and output markets, or effective regulation in those same markets, managers spend more on other prerequisites than is consistent with profit maximization behavior, Gropper \& Oswald (1996). The first empirical work for the Expense Preference Theoretical Framework on financial institutions was carried out by Edwards (1977). Using aggregated bank data for 44 banks in 1962, 1964, 1986 and total wages and salaries; total employees as the dependent variables, he finds the coefficient on the three bank concentration ratios to be positive and significantly correlated with both the bank's total labor force and the bank's total wage bill Thus, he concludes that expense preference behavior is a significant force that detracts from profit maximization in many banks. Other works consistent with this view include the empirical works of (Hannan, 1979 and Arnould, 1985) who found evidence of the expense preference theory in the banking firms. The theory is relevant to this study as it guides on how the profitability of the bank is taken in measuring performance though there are other alternative theories, in which factors other than profitability are taken as a measure of performance.

\subsubsection{Economic Efficiency Theory}

Economic efficiency theory states that companies should achieve their output at the lowest possible cost per unit produced. According to this theory, economies of scale should be exploited to achieve optimal production. The theory focuses on two kinds of efficiency; allocative and productive efficiency. Allocative efficiency is achieved by ensuring that all firms in the industry charge optimal prices. In the banking sector, this will result in a reduction of lending rates.

The economic efficiency theory is relevant to this study as it guides in savings mobilization, which will enable SACCO's to create credit out of excess deposits (credit creation) hence SACCO will earn interest. Allocative efficiency in the determination of lending rates among SACCO's will ensure unhealthy competition does not ensue between them. High competition in banking is associated with instability (De Nicoló, Jalal \& Boyd, 2006). Productive efficiency is achieved when banks employ all their resources efficiently, producing the most output from the least input (Said, 2011). Productive efficiency guides both the lending and investment decisions of financial institutions. It would involve investing in low risk assets such as government bonds. 


\subsection{Empirical Review}

Bataineh, (2014) examined the impact of employee training on the performance of commercial banks in Jordan. The study found that training employees increased their productivity. Increased knowledge and skills leads to efficiency. According to the study, training also increases motivation levels among employees. Productivity of employees is directly tied to performance of banks. A similar study by Tahir \& Sajjad (2013) on commercial banks in Lahore indicated that training significantly influenced bank performance.

Maseki, (2012) studied the impact of knowledge management on performance of commercial banks in Kenya. The study found that knowledge management greatly affected performance of the commercial banks. According to the study knowledge management enhances product and service quality; increases productivity and innovative ability. The study mentioned that knowledge management improves performance of employees in their duties in the bank and enhances employee competence. Knowledge management enhances the ability of the bank to develop new innovative financial products for its customers, turnaround time of employees, communication process in the bank and profitability of the bank.

Kimari, (2013) undertook a study on the relationship between credit risk management and SACCO performance in Kenya. The study used Capital adequacy, Asset quality, Management efficiency, Earnings and Liquidity as the independent variables and ROE as the dependent variable. The study found that the model significantly explained SACCO performance. A positive relationship was found to exist between all the CAMEL components and performance. The study recommended that with regard credit risk management, the management should undertake measures to improve Capital adequacy, Asset quality, Management efficiency, Earnings and Liquidity.

\subsection{Conceptual Framework}

Independent variable

\section{Management efficiency}

-Expenditure to Income

-Ratio Business per Employee

\section{Dependent variable}

Financial Performance of Deposit Taking SACCO's

- ROA

\section{Figure 1: Conceptual Framework}

\subsection{RESEARCH METHODOLOGY}

The study employed an explanatory research design. The target population was all the 83 registered deposits taking SACCO's licensed by SASRA as at 31st December 2011 to 2015 and has been in operation for the last five years. Therefore, the study used the inclusion criteria to select a total of 83 SACCO's registered by SASRA as at 31st December 2011. The sampling frame for the study consisted of all licensed deposit taking SACCO's in operation in Kenya as at 31stDecember, 2011and still in operation as at 31st December 2015 as they appear in the SASRA database. Census methodology was used in the study in order to enable researcher gather sufficient information. The study also used purposive sampling procedure to identify the sample units. The sample size for the study was all 83 SACCO's that have remained in existence since 2011-2015. 
The questionnaire in this study was divided into three parts. The data collected was keyed into Statistical Package for Social Sciences (SPSS) computer software for analysis. SPSS and STATA software was used to produce frequencies, descriptive and inferential statistics which was used to derive a conclusions and generalizations regarding the population.

\subsection{RESULTS AND DISCUSSIONS}

\subsection{Response Rate}

The number of questionnaires that were administered was 83. A total of 71 questionnaires were properly filled and returned. This represented an overall successful response rate of $86 \%$ as shown on Table 1. This agrees with Babbie (2004) who asserted that return rates of 50\% are acceptable to analyze and publish, $60 \%$ is good and $70 \%$ is very good. Based on this assertion $86 \%$ response rate is adequate for the study.

Table 1: Response Rate

\begin{tabular}{lll}
\hline Response & Frequency & Percent \\
\hline Returned & 71 & 86 \\
Unreturned & 12 & 14 \\
Total & $\mathbf{8 3}$ & $\mathbf{1 0 0}$ \\
\hline
\end{tabular}

\subsection{Demographic Characteristics}

This section analyzes the demographic characteristics of the respondents. This section presents the descriptions of the respondents in terms of type of shareholders and period of existence.

\subsubsection{Type of Shareholder}

The respondents were asked to indicate their shareholders. Results in table 2 reveal that $47 \%$ of the respondents indicated business men and women, $42 \%$ of the respondents indicated the general public while $11 \%$ of the respondents indicated government employees. This implies that majority of the SACCOs members and customers are business people and the general public. This implies that most business people rely on SACCOs for finances. This is likely to have a positive influence on Sacco's financial performance.

Table 2: Type of Shareholder

\begin{tabular}{lrr}
\hline Response & Frequency & \multicolumn{2}{c}{ Percent } \\
\hline Government employees & 8 & 11.3 \\
General public & 30 & 42.3 \\
Business Men and Women & 33 & 46.5 \\
Total & $\mathbf{7 1}$ & $\mathbf{1 0 0}$ \\
\hline
\end{tabular}

The respondents were asked to indicate the number of years their organizations have been in existence. Results in table 3 reveal that majority (68\%) of the respondents indicated more than 20 years, $16 \%$ indicated $5-10$ years, $10 \%$ indicated $16-20$ years while $7 \%$ of the respondents indicated 11-15 years. This implies that majority of the SACCOs have been in the market long enough to gain the prerequisite experience and relevance. This implies that the SACCO's have the potential to be competitive and thus performance well. 
Journal of Strategic Management

ISSN 2520-0461 (Online)

Vol.2, Issue 1 No.4, pp 92-104, 2017

www.ajpojournals.org

Table 3: Period of Existence

\begin{tabular}{lrr}
\hline Response & Frequency & \multicolumn{2}{c}{ Percent } \\
\hline 5-10 years & 11 & 15.5 \\
$11-15$ years & 5 & 7 \\
16-20 years & 7 & 9.9 \\
More than 20 years & 48 & 67.6 \\
Total & $\mathbf{7 1}$ & $\mathbf{1 0 0}$ \\
\hline
\end{tabular}

\subsection{Descriptive Statistics}

The objective of the study was to evaluate the influence of management efficiency on financial performance of savings and credit societies in Kenya. The respondents were asked to respond to statements on management efficiency. The responses were rated on a five likert scale as presented in Table 4. Majority of $97 \%(70.4 \%+26.8 \%)$ of the respondents agreed with the statement that observing management efficiency has led to improved business plan of the Sacco, $95 \%$ agreed with the statement that observing management efficiency has led to improved business plan of the Sacco, $70 \%$ of the respondents agreed that observing management efficiency has enhanced independent internal and external audit implementation, $40 \%$ of the respondents agreed that observing management efficiency has enhanced the capability of board of directors and senior management while $82 \%$ of the respondents agreed that observing management efficiency has led to a fit and proper test.

On a five point scale, the average mean of the responses was 3.78 which means that majority of the respondents were agreeing with most of the statements; however the answers were varied as shown by a standard deviation of 0.57 .

The findings agree with those of Bataineh, (2014) who examined the impact of employee training on the performance of commercial banks in Jordan. The study found that training employees increased their productivity. Increased knowledge and skills leads to efficiency. According to the study, training also increases motivation levels among employees. Productivity of employees is directly tied to performance of banks. A similar study by Tahir and Sajjad (2013) on commercial banks in Lahore indicated that training significantly influenced bank performance. 
Journal of Strategic Management

ISSN 2520-0461 (Online)

Vol.2, Issue 1 No.4, pp 92-104, 2017

www.ajpojournals.org

Table 4: Management Efficiency

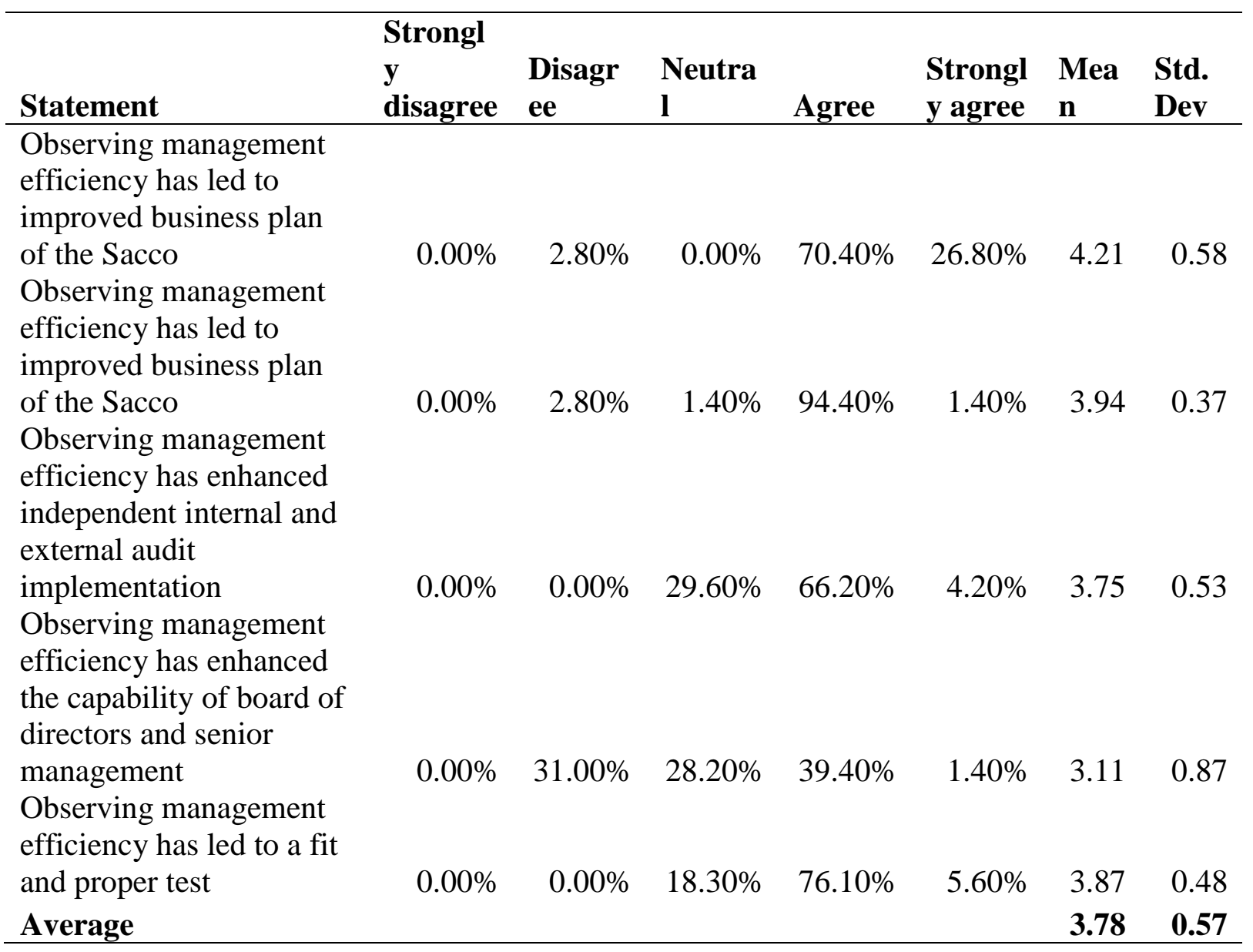

\subsection{Inferential Statistics}

Results in table 5 reveal that management efficiency does not have a significant effect on the financial performance of SACCOs. This can be explained by the fact that the $p$ value of 0.994 which is greater than the critical $\mathrm{p}$ value of 0.05 .

These findings contradicted with those of Maseki (2012) who studied the impact of knowledge management on performance of commercial banks in Kenya. The study found that knowledge management greatly affected performance of the commercial banks. According to the study knowledge management enhances product and service quality; increases productivity and innovative ability.

Table 5: Regression Model

\begin{tabular}{lllll}
\hline Variable & B & Std. Error & t & Sig. \\
\hline (Constant) & 0.395 & 0.289 & 1.36 & 0.173 \\
Management Efficiency & $-2.23 \mathrm{e}-11$ & $3.09 \mathrm{e}-09$ & -0.01 & 0.994
\end{tabular}


Journal of Strategic Management

ISSN 2520-0461 (Online)

Vol.2, Issue 1 No.4, pp 92-104, 2017

www.ajpojournals.org

\subsection{DISCUSSION CONCLUSIONS AND RECOMMENDATIONS}

\subsection{Discussion}

The objective of the study was to evaluate the effect of management efficiency on financial performance of savings and credit societies in Kenya. The regression results showed that there is no significant relationship between management efficiency and financial performance of savings and credit societies as supported by a $p$ value of 0.173 . This implies that improvement in management efficiency would have insignificant impact on the financial performance of savings and credit societies.

\subsection{Conclusions}

Based on the findings the study concluded that management efficiency has no significant influence on the financial performance of savings and credit societies in Kenya. The regression results showed that management efficiency has no significant influence on the financial performance of savings and credit societies $(\mathrm{p}=0.173)$.

\subsection{Recommendations}

The study recommended that with regard to credit risk management, the management should undertake measures to improve Capital adequacy, Asset quality, Management efficiency, Earnings and Liquidity. Further, the study recommended that SACCO's should train their employees as this is likely to increase their productivity.

\subsection{Areas for Further Studies}

The study recommends that a similar study should be conducted in other financial sectors such as banking sector for comparison purposes. The study also recommends that a study seeking to examine the effects of other financial factors on financial performance of savings and credit cooperatives should be conducted. This would help to give insight to the SACCO's and other organizations on what other financial factors to consider in order to enhance their performance.

\section{REFERENCES}

Arnould, R. J. (1985). Agency costs in banking firms: an analysis of expense preference behavior. Journal of Economics and Business, 37(2), 103-112.

Bataineh, K. (2014). Impacts of Employee Training on the Performance of Commercial Banks in Jordan. European Journal of Business and Management, 6(27), 192-196.

Berger, A. N. (1995). The Profit-Structure Relationship in Banking Tests of Market-Power and Efficient-Structure Hypotheses. Journal of Money, Credit and Banking, 27(May 1995), 404-431.

Chaudhry, S., Singh, S. (2012); Impact of Reforms on the Asset Quality in Indian banking .International Journal of Multidisciplinary. 5(2), 17-24.

De Nicolò, G. Boyd, J. H., \& Jalal, A. M. (2006). Bank risk-taking and competition revisited [electronic resource]: new theory and new evidence. International Monetary Fund. 
DeYoung, R. E., Hughes, J. P., \& Moon, C. G. (2001). Efficient risk-taking and regulatory covenant enforcement in a deregulated banking industry. Journal of Economics and Business. 53(2), 255-282.

Edwards, F. R. (1977). Managerial Objectives in Regulated Industries: Expense-Preference Behavior in Banking. Journal of Political Economy. 85(1), 147-161.

Gropper, D. M., \& Oswald, S. L. (1996). Regulation, deregulation and managerial behaviour. Applied Financial Economics, 6(1), 1-7.

Hannan, T. H. (1979). Expense-preference behavior in banking: A reexamination. Journal of Political Economy. 87(October), 891-895.

ICA (2009). 59th Annual Annual Conference.Chicago,IllinoisUSA Chicago Marriott

Infeacho, C \& Ngalawa, H. (2014).Performance of the south African banking sector since 1994. Journal of applied business research (jabr),30(4)1183-1196

John, A. (2002). Rochdale Pioneer. The Oxford Companion to British History .

Kimari, F. N. (2013). Effect of credit risk management on financial performance of deposit taking savings and credit cooperative societies in Kenya (Doctoral dissertation, University of Nairobi).

Kinyua, J. W. (2013). Relationship between financial performance and size of deposit taking Savings and Credit Cooperative Societies in Kenya (Doctoral dissertation, University of Nairobi).

Kioko, C. (2014). Credit information sharing influence on performance of licensed deposit taking SACCO businesses in Kenya. Strategic Journal of Business \& Change Management, 1(2).

Maseki, C. (2012). Knowledge management and performance of commercial banks in Kenya (Doctoral dissertation, University of Nairobi).

Ngaira, L. (2011). The impact of SACCO regulatory authority guidelines on SACCO operations in Kenya-the case of Nairobi deposit taking SACCO's (Doctoral dissertation, School of Business, University of Nairobi).

Ngo'mbe, B.W. \& Mikwamba, E. (2004). Know more about SACCO. A handbook for SACCO study circle programme. Malawi Union of Savings and Credit Cooperative, Lilongwe, Malawi.

Rees, R. (1974). A reconsideration of the expense preference theory of the Firm. Economica, 41(2), 295-307.

Said, R.M., Mohd, H. T,(2011). Performance and financial ratios of commercial banks in Malasia and china. 
Journal of Strategic Management



ISSN 2520-0461 (Online)

Vol.2, Issue 1 No.4, pp 92-104, 2017

www.ajpojournals.org

Smirlock, M. (1985). Evidence of the (Non) Relationship between Concentration and Profitability in Banking. Journal of Money, Credit and Banking, 17(1), 69-83.

Sonja, K. (2010). Effect of computerization on performance of saccos in Uganda. Unpublished MBA research project Reutlingen Germany.

Tahir, A., \& Sajjad, S. (2013). Assessing the Impact of Training on Employees' Performance in Commercial Banks in Urban Lahore.

Thoraneenitiyan, N. (2010). Measuring Bank Peformance in the Current Evolving Market Place. Abac Journal, 30(3), 1-14.

Wanyama, F. O., Develtere, P., \& Pollet, I. (2008). Encountering the evidence: Co-operatives and poverty reduction in Africa. Journal of Co-operative Studies, 41(3), 16-27.

Williamson, O. (1963). Managerial discretion and business behavior. American Economic Review, 53(December), 1032-1057.

Zerfeshewa, B. (2010). Determinants of Saving and Credit Cooperatives (SACCO's) Operational Performance in Gondar town, Ethiopia (Doctoral dissertation, Mekelle University). 